\title{
Isolation and characterisation of lignin-degrading fungus from coir
}

\author{
Adrika Raybarman", Kazi Atikur Rahman*, Russel Miranda Vincent*, \\ Sayantani Chatterjee*, Upasana Sen*, Arup Kumar Mitra*, SudeshnaShyam \\ Choudhury*, Riddhi Majumder* \\ * Department of Microbiology, St. Xavier's College, Kolkata \\ \#Post-graduate Department of Biotechnology, St. Xavier's College, Kolkata
}

\begin{abstract}
Lignin is a complex natural polysaccharide primarily present in secondary wood or secondary xylem and phloem elements of the plant body. It constitutes one-fourth to one-third of the dry mass of wood and also, provides rigidity and strength. Lignin lacks a defined primary structure and is a heterogeneous biopolymer. Lignin-degradation is a major challenge because it can be a potential source of edible polysaccharide including glucose. In this investigation, commercial coir was considered as the source of isolating lignin-degrading fungus. A simple bioassay was carried out in coconut fibre (coir) and wood. In case of the fungal sample, the coir was inoculated in dry and wet conditions which resulted in $5.63 \%$ and $48.35 \%$ degradation respectively. On the basis of this, different lignin-degrading enzymes were assayed and purified. The fungus was identified as Microascus sp. on the basis of colony morphology, spore structure and perithecium formation. Further studies were conducted on the degraded coir and scanning electron microscope (SEM) images were taken. In future, these organisms can be a potential source of ligninolytic enzymes useful in different activities.
\end{abstract}

Keywords: Microascus spp. , Lignolytic Enzymes, Lignin Degradation, Superoxide Dismutase, Laccase, Lignin Peroxidase.

\section{Introduction}

Lignin is a complex aromatic amorphous polymer, most commonly derived from wood and is an integral part of plant cell walls providing mechanical strength to the wall and to plant as a whole (Chabannes et al., 2001). It is a complex natural polysaccharide primarily present in secondary wood on secondary xylem and phloem elements of plant body. It is relatively hydrophobic and aromatic in nature and is known for its heterogeneity in lacking a defined primary structure. It contains three basic monolignol monomeric units which are methoxylated to various degrees: p-coumaryl alcohol, coniferyl alcohol and sinapyl alcohol (Anonymous, 2001; Boerjan et al., 2003; Ralph et al., 2001). Lignin is the second most abundant natural polymer (after cellulose) and forms a matrix surrounding the cellulose, the most abundant biopolymer constituting from a quarter to a third of the dry mass of wood (Boerjan et al., 2003; Lebo et al., 2001). Lignin is indigestible by mammalian and other animal enzymes because of its cross linking with other cell wall components; it also minimizes the accessibility of cellulose and hemicelluloses. Lignin is generally associated with reduced digestibility of the overall plant biomass, which defends against pathogens and pests (Sarkanen and Ludwig, 1971). However, some fungi and bacteria can biodegrade the polymer. A large amount of work is reported from lignin degrading enzymes from white-rot fungi (Basidiomycetes). They are well known for their lignin degrading enzymes, commonly laccase and the perioxidases such as lignin peroxidase (LiP) and manganese peroxidae (MnP) (Reddy, 1995). Lignolytic activity of Ascomycetes have not been reported extensively. Since this encrusting matrix significantly retards microbial depolymerisation of cellulose, the degradation of lignin is a significant step in the global carbon cycle. Furthermore the presence of this intractable polymer is an obstacle to the efficient utilisation of cellulose in a wide range of industrial processes (Gold and Alic, 1993).

\section{Materials And Methods}

\subsection{Sources and collection}

Commercial coir was used as the source of lignin-degrading microbe in this study. It was procured from Beliaghata area in Kolkata, West Bengal.

\subsection{Isolation and purification}

Coir pieces were allowed to decay in vivo. The decayed pieces were then placed on NA and incubated $24.5^{\circ} \mathrm{C}$ for ten days. Subsequently, microbial growth was observed. Pure cultures of fungus were obtained on potato dextrose agar (PDA). 


\subsection{Characterisation of the isolated organism}

The characterisation was done under a compound microscope after staining the fungal sample using Lactophenol Cotton Blue stain.

\subsection{Quantitative estimation of coir degradation \\ 1.4.1 Degradation of coir by fungus}

Coir pieces (dried at $90^{\circ} \mathrm{C}$ for $2 \mathrm{hrs}$ ) of $1 \mathrm{gm}$ each (approx.) in two conditions, wet and dry, were soaked in fungal spore suspension, kept in different petri plates along with a control, incubated at $25^{\circ} \mathrm{C}$ for 21 days after which the dry weights were measured.

\subsection{Degradation activity on wood chips \\ 1.5.1 Degradation of coir by fungus}

Wood shavings (dried at $90^{\circ} \mathrm{C}$ for $2 \mathrm{hrs}$ ) of $1 \mathrm{gm}$ each (approx.) in dry condition, were soaked in fungal spore suspension, kept in different petri plates along with a control, incubated at $25^{\circ} \mathrm{C}$ for 20 days after which the dry weights were measured.

\subsection{Enzyme assay}

Three lignolytic enzymes were identified- laccase, lignin peroxidase (LiP) and manganese peroxidase (MnP). Their assays were done for the fungal sample.

\subsubsection{Laccase enzyme assay (E.C 1.10.3.2)}

The $1 \mathrm{ml}$ fungal extract was made in $50 \mathrm{mM}$ working solution of sodium acetate buffer at $\mathrm{pH}$ 5.0. The assay mixture contained $1 \mathrm{ml}$ of the above extract, $1 \mathrm{ml} 50 \mathrm{mM}$ working solution of sodium acetate buffer $(\mathrm{pH}$ 5.0), $1 \mathrm{ml}$ fresh solution of $2 \mathrm{mM}$ ABTS solution in acetate buffer, $0.5 \mathrm{ml}$ fresh $0.3 \% \mathrm{H}_{2} \mathrm{O}_{2}$ from stock $3 \%$ by doing 1:10 dilution. After a 15 minute incubation time, the O.D was taken at $420 \mathrm{~nm}$.

\subsubsection{Manganese peroxidase enzyme assay (E.C 1.11.1.13)}

Manganese peroxidase activity was determined by monitoring the formation of manganese(III) malonate at $270 \mathrm{~nm}$.Enzyme extract (fungal extract) $1 \mathrm{ml}$ was added to a solution of $\mathrm{MnSO}_{4}(0.2 \mathrm{mM})$-sodium malonate $(50 \mathrm{mM}, \mathrm{pH} 4.5)$, and the reaction was initiated with hydrogen peroxide $(0.1 \mathrm{mM})$ in a final volume of $3 \mathrm{ml}$. The incubation time was $15 \mathrm{~min}$. The initial increase in A270 was determined. The activity was monitored by $\Delta$ O.D. $270 \mathrm{~nm} / \mathrm{min}$.

\subsubsection{Lignin peroxidase enzyme assay (E.C 1.11.1.14)}

Lignin peroxidase assay mixture $(3 \mathrm{ml})$ contains:1) $2.2 \mathrm{ml}$ of dilute supernatant 2) $0.1 \mathrm{ml} 1.2 \mathrm{mM}$ methylene blue 3) $0.6 \mathrm{ml}$ of $0.5 \mathrm{M}$ sodium tartrate buffer ( $\mathrm{pH} 4)$. The reaction was started by addition of $0.1 \mathrm{ml}$ of $2.7 \mathrm{mM}$ of $\mathrm{H}_{2} \mathrm{O}_{2}$. The conversion of the dye to azure $\mathrm{C}$ was monitored by the measurement of the decrease of the absorbance at $664 \mathrm{~nm}$. The results were expressed as change of absorbance per minute $\left(\Delta \mathbf{O . D}_{664 \mathrm{~nm}} / \mathbf{m i n}\right)$.

\subsection{Enzyme separation}

The 21-day fungal cultures were first filtered using filter paper. The filtrate was centrifuged at 5000 rpm for 12 min.Potassium phosphate buffer ( $\mathrm{pH}$ 5.8) was the running buffer for the DEAE Sephadex anion exchange column (HIMEDIA DEAE Sephadex A-50). The samples were eluted with a linear gradient of 0.3-0.9 $\mathrm{M} \mathrm{NaCl}$ in the same buffer with a flow rate of $0.6 \mathrm{ml} \mathrm{min}^{-1}$. The fractions containing the proteins were collected and the eluents were assayed to determine enzymatic activity.

\subsection{SEM imaging}

Scanning electron microscope (SEM) imaging was done to determine the changes caused in the coir fibre structure during degradation. Three samples were studied: control (untreated coir fibre), coir fibre treated with fungal sample and the last, with the bacterial sample (incubated at $37^{\circ} \mathrm{C}$ for a period of 21 days each).

\section{a. Characterisation of fungal sample}

\section{Results}

The fungal specimen after simple wet-mount staining under a microscope was observed as a hyphal meshwork with micro-spores observed in older culture. The fungal species was identified as Microascus spp.

\section{b. Percentage degradation of coir \\ Fungal sample}


The coir which was taken in dry condition showed $5.63 \%$ more degradation with respect to the control. In the case of the wet coir, the percentage degradation was recorded to be $48.35 \%$ more as compared to the control.

\section{c. Percentage degradation of wood chips}

The wood chips inoculated with the bacterial sample showed $4.7 \%$ decrease in dry weight whereas $2.2 \%$ degradation was observed in those inoculated with the fungal sample.

The decrease in degradation activity with respect to coir can be attributed to the fact that processed wood in the experiment. This added a toxicity factor which inhibited the growth of microbes.

\section{d. Enzyme assay}

\section{i. Enzymes in the presence of coir}

In case of fungus sample without coir, the enzymatic activity for laccase and manganese peroxidase was found to be $0.23 \mathrm{U} / \mathrm{ml}, 0.95 \mathrm{U} / \mathrm{ml}$ respectively and activity of lignin peroxidase was absent.

In case of fungus sample with coir, the enzymatic activity for laccase, manganese peroxidase and lignin peroxidase were $0.59 \mathrm{U} / \mathrm{ml}, 1 \mathrm{U} / \mathrm{ml}$ and $0.45 \mathrm{U} / \mathrm{ml}$ respectively. Table 4.1 illustrates this very well.

\section{ii. Enzymes in the presence of wood shavings}

In case of fungus sample with wood shavings, the enzymatic activity for laccase, and manganese peroxidase were $0.60 \mathrm{U} / \mathrm{ml}, 0.23 \mathrm{U} / \mathrm{ml}$ respectively. Please refer to Table 4.2.

\section{e. $\quad$ Enzyme separation}

The enzymes were purified and specific activities of laccase, lignin peroxidase and manganese peroxidase were found to be $0.60 \mathrm{U} / \mu \mathrm{g}, 0.74 \mathrm{U} / \mu \mathrm{g}$ and $1.00 \mathrm{U} / \mu \mathrm{g}$ respectively. Please refer to Table 4.3.

\section{f. SEM imaging}

In the control, the diameter of the xylem tracheids was observed to be small and the structure of the fibre was compact. [Fig 1] The SEM images of the coir fibre treated with the fungal sample reveal the extent of loss of orderliness and compactness of the structure. They also highlighted the fact that the fungus causes degradation by sloughing off the coir fibre. [Fig 2].

\section{Tables And Figures}

4.1 Enzyme assay in the presence of coir

\begin{tabular}{lccc}
\hline & Enzyme activity in U/ml & & \\
\hline SAMPLE & Laccase & MnP & LiP \\
\hline Fungus (control) & 0.23 & 0.95 & - \\
\hline Fungus (with coir) & 0.59 & 1.00 & 0.45
\end{tabular}

4.2 Enzyme assay in presence of wood chips

Enzyme activity in U/ml

\begin{tabular}{lccc}
\hline SAMPLE & Laccase & MnP & LiP \\
\hline Fungus (control) & 0.23 & 0.95 & - \\
\hline $\begin{array}{l}\text { Fungus (with wood } \\
\text { shavings) }\end{array}$ & 0.60 & 0.23 & - \\
\hline
\end{tabular}

\subsection{Enzyme separation(Ion Exchange Chromatography)}

\begin{tabular}{lcccc}
\hline Enzyme & $\begin{array}{c}\text { Elution conc. of } \\
\mathbf{N a C l}(\mathbf{M})\end{array}$ & $\begin{array}{c}\text { Activity } \\
(\mathbf{U} / \mathbf{m l})\end{array}$ & $\begin{array}{c}\text { Total protein } \\
(\boldsymbol{\mu g} / \mathbf{m l})\end{array}$ & $\begin{array}{c}\text { Specific activity } \\
(\mathbf{U} / \boldsymbol{\mu g})\end{array}$ \\
\hline Laccase & 0.9 & 0.12 & 0.20 & 0.60 \\
\hline LiP & 0.3 & 0.25 & 0.35 & 0.74 \\
\hline MnP & 0.5 & 0.30 & 0.30 & 1.00 \\
\hline
\end{tabular}




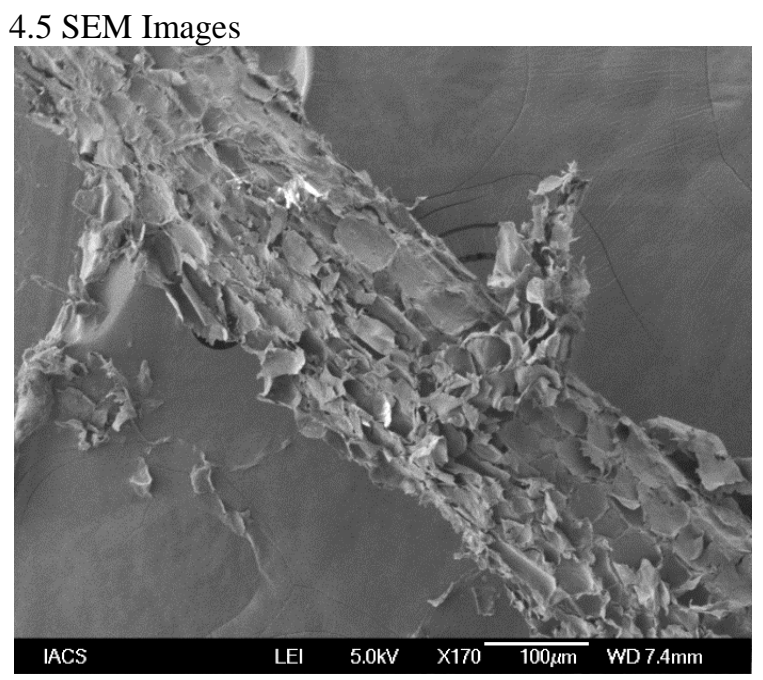

a. Control fibre [Figure 1]

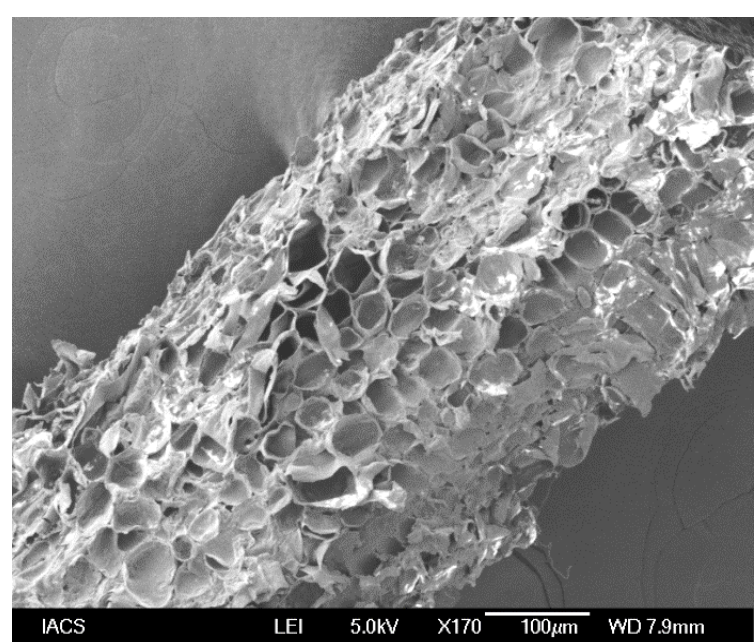

b. Coir treated with fungus [Figure 2]

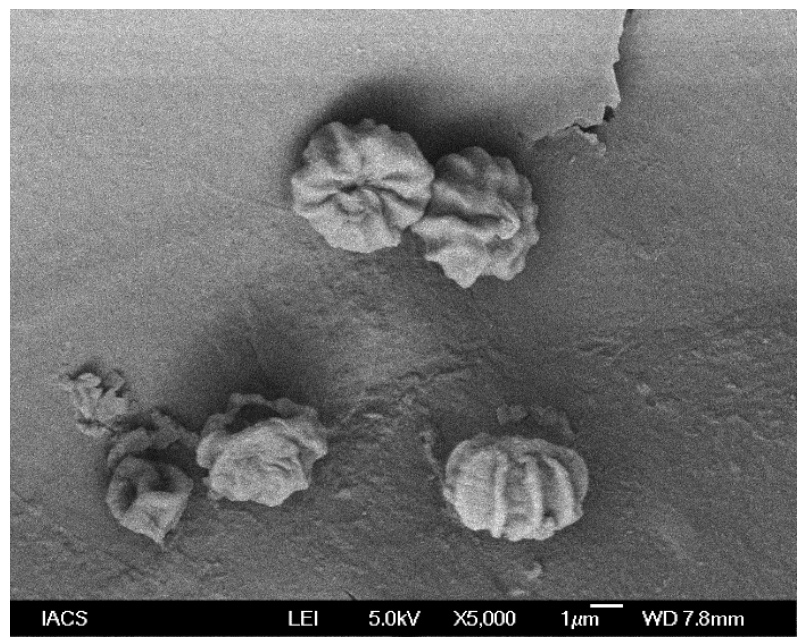

\section{Conclusion}

Apart from the fungus under study (ascomycetes) there are known fungi, mostly white rot fungi, belonging to the class basidiomycetes (commonly studied Trametes versicolor and Phanerochaete chrysosporium) known for their lignolytic activity.T. versicolor has an optimum temperature of around $40-50{ }^{\circ} \mathrm{C}$ and $\mathrm{pH}$ around $4-5$. P. chrysosporium requires a temperature range of $34-38{ }^{\circ} \mathrm{C}$ and $\mathrm{pH} 4.2-4.5$. The fungus, Microascus sp, has a temperature range of $25-27{ }^{\circ} \mathrm{C}$ and $\mathrm{pH}$ 5.5-5.6.T. versicolor was recorded to produce $26.9 \%$ degradation of lignin after a period of 60 days (source of lignin was Acacia wood chips). P. chrysosporium was found to achieve degradation of about 90-100\% after a period of 11 days but the source used was Kraft lignin, i.e. lignin in the purified form. Microascus sp. was found to achieve total degradation of $48.35 \%$ after a period of 21 days from natural lignin source (coir).

Lignin can be a potential carbohydrate source for animal and fish food. Lignin degraded oligosaccharides can be used for mushroom cultivation. It is used as a carbohydrate source in microbial media. The isolated enzymes can be used for bio-remediation and recycling of lignin. They can be used for nylon degradation. Lignin can be separated from cellulose which can be used as a raw material for the paper industry. The genes coding for the lignin-degrading enzymes can be sequenced and produced in vivo. The genes can also be incorporated in other bacteria like E. coli through plasmids making even those cells capable of lignin degradation. The purified enzyme can be used for converting rough coir to smooth form used by the coir industries. The products of these industries can be used as an additional substitute for plastic, solving a major ecological problem as well.

\section{Acknowledgement}

For our work, we would like to acknowledge the head of our institution St.Xaviers' College - Rev. Fr. Felix Raj, the head of our Microbiology Department - Dr. Kasturi Sarkar, and our professors - Dr. Sudeshna 
Shyam Choudhury and Dr. Riddhi Majumdar for constantly guiding us throughout our project.

\section{References}

[1]. Isolation and characterization of novel bacterial strains exhibiting ligninolytic potential, Bandounas et al. BMC Biotechnology 2011, 11:94.

[2]. Manganese regulation of manganese peroxidase expression and lignin degradation by the white rot fungus Dichomitus squalens, $\mathrm{F}$ H Périé and M H Gold, Appl. Environ. Microbiol. 1991, 57(8):2240.

[3]. Purification and characterization of a phenoloxidase (laccase) from the lignin-degrading basidiomycete PM1 (CECT 2971), Coll et al. Appl. Environ. Microbiol. 1993, 59(8):2607.

[4]. Decolorization of Azo, Triphenyl Methane, Heterocyclic, and Polymeric Dyes by Lignin Peroxidase Isoenzymes from Phanerochaete chrysosporium, Ollikka et al. Appl. Environ. Microbiol. 1993, 59(12):4010.

[5]. Use of holomorph characters to delimit Microascus nidicola and M. soppii sp. nov., with notes on the genus Pithoascus, Abbott et al. Mycologia, 94(2), 2002, pp. 362-369.

[6]. Induction of Laccase Production and Analysis of Laccase Isozymes in Trichophyton rubrum LKY-7, Shin et al. J. Korean Soc. Appl. Biol. Chem. 53(2), 158-163 (2010).

[7]. The Lignin-degrading enzyme, Laccase from Marine Fungi; Biochemical and Molecular Approaches, Thesis submitted for the degree of Doctor of Philosophy to the Goa University by Donna Trella D' Souza-Ticlo, National Institute of Oceanography, Goa (Oct. 2008).

[8]. Manganese Peroxidase, Produced by Trametes versicolor during Pulp Bleaching, Demethylates and Delignifies Kraft Pulp--M. G. PAICE,* I. D. REID, R. BOURBONNAIS, F. S. ARCHIBALD, AND L. JURASEK- APPLIED AND ENVIRONMENTAL MICROBIOLOGY, Jan. 1993, p. 260-265; Vol. 59, No. 1.

[9]. Demonstration of Laccase in the White Rot Basidiomycete Phanerochaete chrysosporium BKM-F176 C. SRINIVASAN,1,2 T. M. D'SOUZA,1 K. BOOMINATHAN,AND C. A. REDDY: APPLIED AND ENVIRONMENTAL MICROBIOLOGY, Dec. 1995, p. 4274-4277 Vol. 61, No. 12.

[10]. Purification and characterization of manganese peroxidase fromwood-degrading fungus Trichophyton rubrum LSK-27, Bermek et al. Enzyme and Microbial Technology 35 (2004) 87-92. 